\title{
NOTES
}

\section{PROSPECTIVE BOYS MARKETS INJUNCTIVE RELIEF: A LIMITED REMEDY FOR VIOLATION OF COLLECTIVE BARGAINING NO-STRIKE AGREEMENTS}

In the 1970 case of Boys Markets, Inc. v. Retail Clerks Local $770,{ }^{1}$ the Supreme Court reversed its holding of eight years before ${ }^{2}$ by declaring that the anti-injunctive provisions of the Norris-LaGuardia $\mathrm{Act}^{3}$ do not prohibit injunctive relief against a strike over an arbitrable grievance in violation of a no-strike clause in a collective bargaining agreement. Since then, employers faced with repeated strikes and work stoppages have sought injunctive relief not only to halt immediate strike activity, but also to prevent recurrence of the same or similar disruptions. Although the Supreme Court has not yet considered the question of the prospective use of Boys Markets injunctions, several courts of appeals have done $\mathrm{so}^{4}$ with widely differing results.

This Note will consider the permissibility of prospective injunctive relief for repeated breaches of contractual no-strike clauses. Essential background will be provided by a brief review of the development of legislative and judicial policy from the passage of the Norris-LaGuardia Act to the rendering of the Boys Markets decision. A brief discussion of Boys Markets itself, with particular emphasis on its self-imposed limitations, will follow. The six circuit court cases dealing with prospective Boys Markets relief will be discussed and the principal legal issues and arguments presented in each of the opinions will be compared and analyzed. Finally, in endorsing the decisions of those courts which have adopted the more restrictive approach, this Note will propose several carefully defined limitations on the use of prospective injunctions in private labor contract disputes.

\section{Legislative and Judicial Policy Development}

Congress responded to widespread criticism of abuses in the use of

1. 398 U.S.235 (1970).

2. Sinclair Ref. Co. v. Atkinson, 370 U.S. 195 (1962).

3. 29 U.S.C. $\$ 104($ a) (1970), quoted in note 11 infra.

4. United States Steel Corp. v. UMW, 534 F.2d 1063 (3rd Cir. 1976); Donovan Constr. Co. v. Construction Laborers Local 383, 533 F.2d 481 (9th Cir. 1976); United States Steel Corp. v. UMW, 519 F.2d 1236 (5th Cir. 1975), cert. denied, 96 S. Ct. 3221 (1976); CF\&I Steel Corp. v. UMW, 507 F.2d 170 (10th Cir. 1974); Old Ben Coal Corp. v. Local 1487 UMW, 500 F.2d 950 (7th Cir. 1974); Old Ben Coal Corp. v. Local 1487 UMW, 457 F.2d 162 (7th Cir. 1972). 
injunctive relief in labor disputes ${ }^{5}$ by enacting the Norris-LaGuardia Act $^{6}$ in $1932 .{ }^{7}$ Among those practices contributing to what had been characterized by organized labor as "government by injunction"s were the issuance of injunctions ex parte on the basis of affidavits alone, the often unlimited breadth and scope of such injunctions, their enforcement by fine or imprisonment, and the absence of a right to jury trial for violations. ${ }^{9}$ The Act, which sought to eradicate such abuses, declared its objective to be the protection of workers' rights to organize themselves as a counterbalance to government's historic support of the power of organized capital. ${ }^{10}$ It explicitly withdrew the federal courts' jurisdiction to issue any temporary restraining order, preliminary injunction or permanent injunction in cases arising from or involving labor disputes. ${ }^{11}$

In 1947, the Labor-Management Relations Act (Taft-Hartley Act) ${ }^{12}$ was passed, aimed at rectifying a new imbalance ${ }^{13}$ which had arisen in the struggle between labor and management. ${ }^{14}$ Of particular significance is section 301(a) of the Act, which provides that:

Suits for violation of contracts between an employer and a labor organization representing employees in an industry affecting commerce as defined in this chapter, or between any such labor organizations, may be brought in any district court of the United States having jurisdiction of the parties, without respect to the amount in controversy or without regard to the citizenship of the parties. ${ }^{15}$

5. See generally F. FRANKFURTER \& N. GREENE, THE LABOR INJUNCTION (1930).

6. 29 U.S.C. $\S 101$ et seq. (1970).

7. A. Goldman, The Supreme Court and labor-Management Relation law 25 (1976).

8. Statutory History of the United States: Labor Organization 162 (R. Koretz ed. 1970).

9. H. Wellington, Labor and the Legal Process $39-40$ (1968). See also Statutory HisToRY, supra note 8, at 181-85.

10. See 29 U.S.C. \& $102(1970)$.

11. No court of the United States shall have jurisdiction to issue any restraining order or temporary or permanent injunction in any case involving or growing out of any labor dispute to prohibit any person or persons participating or interested in such dispute ... from doing, whether singly or in concert, any of the following acts:

(a) Ceasing or refusing to perform any work or to remain in any relation of employment; . . .

Id. $\$ 104$. The Act defines a "labor dispute" as

any controversy concerning terms or conditions of employment, or concerning the association or representation of persons in negotiating, fixing, maintaining, changing, or seeking to arrange terms or conditions of employment, regardless of whether or not the disputants stand in the proximate relation of employer and employee.

Id. § $113(\mathrm{c})$.

12. Id. §§ 141 et seq.

13. In the report of the Senate Committee on Labor and Public Welfare submitted by Robert Taft, the inadequacy of existing industrial relations law was stressed and the argument made that union activities had been placed 'beyond the pale of Federal law.' STATUTORY HisTORY, supra note 8, at 589-90.

14. See 29 U.S.C. § 151 (1970).

15. Id. § 185(a). 
The legislative history of section 301 is "cloudy and confusing," "16 but interpretation of its purpose by the Supreme Court, most recently in the Boys Markets decision, indicates that the section is to function in accommodation with rather than in opposition to the Norris-LaGuardia Act. In Textile Workers Union v. Lincoln Mills, ${ }^{17}$ the Court held that a federal court could, under the authority of section 301(a), compel arbitration of disputes where such arbitration was provided for in the collective bargaining agreement. ${ }^{18}$ While the federal courts' power to enforce agreements to arbitrate was thus clearly established, ${ }^{19}$ the question remained whether a similar view should obtain with respect to injunctive relief against strike activity in violation of an agreement to submit disputes to arbitration. The resolution of this issue necessitated the reconciliation of two seemingly antithetical statutes: the Norris-LaGuardia Act, which apparently removed the federal judiciary from labor disputes, and the Taft-Hartley Act, which allowed renewed judicial participation. ${ }^{20}$ The first occasion for Supreme Court resolution of this conflict was provided in Sinclair Refining Co. v. Atkinson. ${ }^{21}$

In Sinclair, a majority of the Court affirmed the dismissal of an employer's suit for injunctive relief against a strike over an arbitrable grievance which violated a no-strike clause in the collective bargaining agreement. The majority relied principally on the fact that Congress, in enacting Taft-Hartley, had expressly declined to repeal the straightforward prohibitions of the Norris-LaGuardia Act. Absent such congressional action, the majority concluded, those prohibitions remained in effect. ${ }^{22}$ In dissent, Justice Brennan endorsed an "accommodation" approach to the two statutes. ${ }^{23} \mathrm{He}$ advocated a balancing of the competing policy considera-

16. Textile Workers Union v. Lincoln Mills, 353 U.S. 448, 452 (1957).

17. 353 U.S. 448 (1957).

18. Justice Douglas, delivering the opinion of the Court, quoted the legislative history, see S. Rep. No. 105, 80th Cong., 1st Sess. 16 (1947), to support the Court's decision that the enforceability of collective bargaining agreements is the chief inducement for employers to enter into such contracts. "Plainly," Justice Douglas reasoned, "the agreement to arbitrate grievance disputes is the quid pro quo for an agreement not to strike." 353 U.S. at 455.

19. See also United Steelworkers v. American Mfg. Co., 363 U.S. 564 (1960); United Steelworkers v. Warrior \& Gulf Navigation Co., 363 U.S. 574 (1960); United Steelworkers v. Enterprise Wheel \& Car Corp., 363 U.S. 593 (1960). These cases, often referred to as the "Steelworkers Trilogy," reaffirmed the congressional policy favoring resolution of labor disputes through enforced arbitration where the parties had agreed by contract to arbitration procedures.

20. See Gould, On Labor Injunctions, Unions, and the Judges: The Boys Markets Case, 1970 SUP. CT. Rev. 215, 219-20.

21. 370 U.S. 195 (1962).

22. Id. at 203. This reasoning was based on an extensive analysis of the legislative history of section 301. Id. at 203-12 (Black, J.); see A. GoldMaN, supra note 7, at 117. Further, the Court rejected the argument that section 301 had, if nothing else, conferred on the courts the power to "accommodate" the provisions of the seemingly contradictory statutes. 370 U.S. at 209. The Court concluded by deferring to the legislature, stating that any reform of the Norris-LaGuardia Act would have to come from Congress. Id. at 214-15.

23. Of course $\S 301$. . did not, for purposes of actions brought under it, "repeal" 
tions, observing that "the availability of the injunctive remedy in this setting is far more necessary to the accomplishment of the purposes of $\S 301$ than it would be detrimental to those of Norris-LaGuardia." 24

\section{THE BOYS MARKETS DECISION}

In 1970 , Boys Markets, Inc. v. Retail Clerks Local $770^{25}$ presented the Court with an opportunity to acknowledge Sinclair's disharmony with the accepted national policy of promoting peaceful settlement of labor disputes through arbitration, to re-examine the soundness of that holding, and to overrule it. Justice Brennan, now writing for the majority, observed that developments subsequent to Sinclair had demonstrated that the holding of that case frustrated rather than furthered the goals of national labor policy. ${ }^{26}$

$\S 4$ of the Norris-LaGuardia Act. But the two provisions do co-exist, and it is clear beyond dispute that they apply to the cases before us in apparently conflicting senses. Our duty, therefore, is to seek out that accommodation of the two which will give the fullest possible effect to the central purposes of both.

370 U.S. at 215-16 (Brennan, J., dissenting).

24. Id. at 218 (Brennan, J., dissenting). That is, while labor's loss of its strike weapon is at least partially compensated by its ability to obtain specific enforcement of the employer's obligation to arbitrate (thus preventing the inequitable disarming of labor to which the NorrisLaGuardia Act was addressed), the enjoining of a strike over an arbitrable grievance may be essential to the enforcement of the arbitration agreement. Without this power to enjoin, the district court may be crippled in the performance of its section 301 function. Id. at 216-19.

It is interesting to note that the injunction sought in Sinclair would have required prospective application, and Justice Brennan recognized in his dissenting opinion the added complexity of a request for future relief:

[T] he court should remand the case to the District Court with directions to consider whether to grant the relief sought - an injunction against future repetitions. This would entail a weighing of the employer's need for such an injunction against the harm that might be inflicted upon legitimate employee activity. It would call into question the feasibility of setting up in futuro contempt sanctions against the union (for striking) and against the employer (for refusing to arbitrate) in regard to prospective disputes which might fall more or less clearly into the adjudicated category of arbitrable grievances. In short, the District Court will have to consider with great care whether it is possible to draft a decree which would deal equitably with all the interests at stake.

Id. at $228-29$.

25. 398 U.S. 235 (1970). The dispute originated with union insistence that work done by non-union employees of petitioner's supermarket be done again by union personnel. Petitioner's refusal was followed by work stoppage and picketing, despite the provisions of the collective bargaining agreement to which Boys Markets and the union were parties requiring that all disputes over its interpretation be resolved through arbitration without work stoppage. When the union refused to terminate the strike and comply with arbitration procedures, Boys Markets sought injunctive relief in state court.

Following the state court's issuance of a temporary restraining order, the union removcd the case to the federal district court and moved to quash the state court's order. The district court, however, found the dispute arbitrable under the agreement and held the strike to be in breach of contract. The strike was enjoined and arbitration ordered. The Court of Appeals for the Ninth Circuit reversed in recognition of the Supreme Court's holding in Sinclair v. Atkinson that $\S 4$ of the Norris-LaGuardia Act prohibits such injunctive relief even where the collective bargaining agreement provides mandatory arbitration procedures.

The Supreme Court reversed the Ninth Circuit's decision, remanding with directions to enter judgment affirming the order of the district court.

26. Id. at 241. Paramount among these developments was the Court's decision in Avco 
The Court also noted the inadequacy of the remaining forms of relief available to employers in section 301(a) suits under the Sinclair holding: damages awarded after the dispute had been settled might be a poor substitute for immediate cessation of the strike, and a damage action prosecuted in the aftermath of a labor dispute might aggravate employee dissatisfaction and delay resolution of differences. ${ }^{27}$ The Court endorsed the accommodation approach urged by the Sinclair dissent, ${ }^{28}$ which it believed to be consistent with the gradual shift in federal labor policies, from NorrisLaGuardia to Taft-Hartley, as economic conditions and labor relations had evolved. ${ }^{29}$

The Boys Markets opinion concluded by insisting that its holding was a "narrow one," 30 carefully tailored to leave intact the vitality of the NorrisLaGuardia Act. The restricted dimensions of the appropriate conditions for approval of injunctive relief are to be measured by the principles announced in the Sinclair dissent, as explicitly adopted ${ }^{31}$ by the Boys Markets Court:

"A District Court entertaining an action under $\S 301$ may not grant injunctive relief against concerted activity unless and until it decides that the case is one in which an injunction would be appropriate despite the Norris-LaGuardia Act. When a strike is sought to be enjoined

Corp. v. Aero Lodge 735, 390 U.S. 557 (1968). In Avco, the Court held that section 301 (a) suits initiated in state courts could be removed to federal courts under federal question jurisdiction, pursuant to 28 U.S.C. $\$ 1441$ (1970). The incentive for union defendants to remove to federal court in order to take advantage of the injunction prohibitions of the Norris-LaGuardia Act was obvious. The result directly contravened the congressional purpose in enacting section 301(a) to supplement rather than usurp pre-existing state court jurisdiction. See Boys Markets, Inc. v. Retail Clerks Local 770, 398 U.S. 235, 245 (1970). The combined effect of Sinclair and Avco was to oust state courts of jurisdiction in section 301(a) suits for injunctive relief, to encourage "rampant forum shopping," and to frustrate any uniformity in arbitration agreement enforcement by creating inconsistencies in the availability of vital injunctive relief. Id. at 243-46.

27. 398 U.S. at 248. See also ABA LABOR Relations Section, Report of SPeCial Atkinson-Sinclair COMMITIEE, pt. 2, at 226 (1963). The report of the committee's neutral members rejected the efficacy of damage relief and the remedy of employer disciplinary action.

28. 398 U.S. at 250 .

29. The Norris-LaGuardia Act was responsive to a situation totally different from that which exists today. In the early part of this century, the federal courts generally were regarded as allies of management in its attempt to prevent the organization and strengthening of labor unions; and in this struggle the injunction became a potent weapon that was wielded against the activities of labor groups .... As labor organizations grew in strength and developed toward maturity, congressional emphasis shifted from protection of the nascent labor movement to the encouragement of collective bargaining and to administrative techniques for the peaceful resolution of industrial disputes. This shift in emphasis was accomplished, however, without extensive revision of many of the older enactments, including the anti-injunction section of the Norris-LaGuardia Act. Thus it became the task of the courts to accommodate, to reconcile the older statutes with the more recent ones.

Id. at $250-51$.

30. Id. at 253. The Court found that while the central purpose of Norris-LaGuardia would not be sacrificed by the "limited use of equitable remedies" to further the policy of arbitration, id., it does not "follow from what we have said that injunctive relief is appropriate as a matter of course in every case of a strike over an arbitrable grievance." Id. at 253-54.

31. Id. at 254 . 
because it is over a grievance which both parties are contractually bound to arbitrate, the District Court may issue no injunctive order until it first holds that the contract does have that effect; . . . Beyond this, the District Court must, of course, consider whether issuance of an injunction would be warranted under ordinary principles of equitywhether breaches are occurring and will continue, or have been threatened and will be committed; whether they have caused or will cause irreparable injury to the employer; and whether the employer will suffer more from the denial of an injunction than will the union from its issuance." ${ }^{32}$

\section{Prospective ApPlication: Conflict AMONG tHe Circuits}

Boys Markets injunctions have been issued in a variety of situations since 1970, and considerable controversy has arisen over the propriety of their issuance. ${ }^{33}$ One area of recent controversy is the permissibility of prospective Boys Markets injunctive relief for repeated violations of employees' contractual no-strike obligations.

The most useful foundation for analyzing the prospective injunction question was provided by the Court of Appeals for the Seventh Circuit in Old Ben Coal Corp. v. Local 1487 UMW (Old Ben I). ${ }^{34}$ In that case, the union had appealed a broad injunction issued by the district court which prohibited the union from continuing its current strike at the Old Ben mines and enjoined future strikes over any arbitrable grievances which might arise during the life of the National Bituminous Coal Wage Agreement (NBCWA) $)^{35}$ of $1968 .{ }^{36}$ In issuing the broad injunction, the district court had

32. Id. (quoting Sinclair Ref. Co. v. Atkinson, 370 U.S. at 228 (Brennan, J., dissenting)). This enunciation of guidelines in the Sinclair dissent reappears in almost all of the court of appeals decisions considered infra.

33. One of the most frequently debated areas of application was that of sympathy strikes. See, e.g., Note: The Applicability of Boys Markets Injunctions to Refusals to Cross a Picket Line, 76 Colum. L. REv. 113 (1976); Comment, Labor Law: The Avallability of Federal Injunctive Relief to Halt Sympathy Strikes, 9 CREIGHTON L. REV. 613 (1976); cf. United States Steel Corp. v. UMW, 519 F.2d 1236, 1244 n.15 (5th Cir. 1975), cert. denied, 96 S. Ct. 3221 (1976).

The Supreme Court finally resolved the controversy in Buffalo Forge Co. v. United Steelworkers, $96 \mathrm{~S}$. Ct. 3141 (1976), concluding that sympathy strikes, because they do not involve disputes between management and the union striking in sympathy, may not be enjoined pending an arbitrator's decision as to whether the strike is forbidden by the parties' contractual no-strike commitment. See id. at 3147 n. 10 for a compilation of court of appeals positions on the sympathy strike issue.

34. 457 F.2d 162 (7th Cir. 1972).

35. The National Bituminous Coal Wage Agreement is the collective bargaining agreement under which all but one (Donovan Constr. Co. v. Construction Laborers Local 383, 533 F.2d 481 (1976)) of the circuit court cases considered here were brought. Versions of the NBCWA, effective for a three-year period, were signed in 1968, 1971 and 1974 between the Bituminous Coal Operators' Association and the United Mine Workers.

36. 457 F.2d at 163. The strike which gave rise to the suit in Old Ben I had been initiated to 
relied on findings of repeated work stoppages over arbitrable grievances. ${ }^{37}$ The Seventh Circuit reversed the district court's grant of prospective injunctive relief with little discussion of the implications of such a remedial measure. It modified the district court's order, deleting the expansive prospective prohibition in recognition of the "cautious approach" mandated by the existence of the Norris-LaGuardia Act. ${ }^{38}$ The court reserved the option of approving such broad prospective relief at a later date should the union prove unwilling to comply with the district court's determination of its rights. ${ }^{39}$

The Seventh Circuit exercised that option two years later in the second Old Ben Coal Corp. v. Local 1487 UMW (Old Ben II)..$^{40}$ The court affirmed without modification a permanent injunction against work stoppages and strikes over arbitrable differences under the NBCWA of 1971 for the life of that agreement. In refuting the umion's claims of overbreadth and vagueness, ${ }^{41}$ the court emphasized that the language of the injunction was taken directly from the parties' contractual agreement, ${ }^{42}$ and that the union would not be prejudiced by a broad prospective injunction, even in close cases where the arbitrability of the grievance might be unclear, because of its right to seek declaratory relief. ${ }^{43}$

In the same year, the propriety of broad prospective injunctive relief in arbitrable labor disputes and the prerequisites for such relief were discussed and somewhat refined in CF\&I Steel Corp. v. UMW. ${ }^{44}$ The trial court ${ }^{45}$ had reviewed a series of work stoppages over various arbitrable grievances concerning employee discharges, suspensions, work assignments, portal-toportal pay, medical services, vacation pay and hoistmen's pay, and had concluded that only the first three of these grievances were likely to cause

protest the discharge of a union member-an arbitrable grievance under the NBCWA. See id. at 164-65.

For a discussion of the application of prospective injunctions to the particular conditions of the coal mining industry, see Note, Prospective Boys Markets Injunctions, 90 HARv. L. REv. 790 (1977).

37. 457 F.2d at 165. This strike was determined to be the thirteenth such stoppage over an arbitrable dispute since the NBCWA had gone into effect. Id. at 163. The court also found that the employer had sustained irreparable injury which would continue unless work stoppages were enjoined, for the coal mining industry was operating at full capacity and production time lost could never be recovered. Id.

38. Id. at 165 .

39. Id.

40. 500 F.2d 950 (7th Cir. 1974).

41. Id. at 953 .

42. Id.

43. Id.

44. 507 F.2d 170 (10th Cir. 1974).

45. CF\&I Steel Corp. v. UMW, 372 F. Supp. 846 (D. Colo. 1973), aff'd, 507 F.2d 170 (10th Cir. 1974). 
recurring stoppages. ${ }^{46} \mathrm{An}$ injunction was therefore issued ordering that the miners "be . . . enjoined from engaging in a strike [or] work stoppage ... at the Allen Mine . . . over disputes arising from employee suspensions, employee discharges, and work assignments, during the remaining life of the National Bituminous Coal Wage Agreement of 1971." "47

On appeal, the Tenth Circuit affirmed, rejecting union objections of vagueness and overbreadth similar to those raised in Old Ben II. The CF\&I court adopted as its principal criterion for the granting of prospective relief the language of the Boys Markets opinion which incorporated Justice Brennan's Sinclair dissent: " "The District Court must, of course, consider ... whether breaches are occurring and will continue or have been threatened and will be committed . . . ." "48 The Tenth Circuit concluded that where, as here, the record disclosed "an unlawful proclivity . . . to pursue a course of conduct in violation of the agreement of the parties . . .," 49 the proper scope of injunctive relief, viewed in terms of Boys Markets' balancing of the policies of Norris-LaGuardia and section 301, was not exceeded by a prospectively applied decree.

A similar assortment of disputes resulting in work stoppages precipitated a dramatically different result the following year in United States Steel Corp. v. UMW (U.S. Steel (5th Cir.)). ${ }^{50}$ There, the Court of Appeals for the Fifth Circuit reviewed an injunction which prohibited, for the last year of the 1971 NBCWA's term, any strike or work stoppage "over any disagreement about the interpretation or application of the collective bargaining agreement between the parties or any disagreement over any matter not mentioned in said agreement, or over local trouble of any kind." 51 The district court ${ }^{52}$ had justified issuance of the injunction by pointing to the implied approval of prospective injunctive relief in the Sinclair dissent ${ }^{53}$ and by reference to the record, which showed a pattern of strikes and disobedience of temporary restraining orders. ${ }^{54}$ In an analytically thorough opinion by Judge Wisdom, the Fifth Circuit rejected the district court's rationale and reversed its decision, though sympathizing with its apparent exasperation in the face of repeated strikes over arbitrable issues and

46. 372 F. Supp. at 853 .

47. Id.

48. 507 F.2d at 176 (quoting Boys Markets, Inc. v. Retail Clerks Local 770, 398 U.S. 235, 254 (1970)) (emphasis by court of appeals).

49. Id. at 176-77.

50. 519 F.2d 1236 (5th Cir. 1975), cert. denied, 96 S. Ct. 3221 (1976).

51. Like the injunction in Old Ben $I$, the language of the order was taken directly from the NBCWA.

52. United States Steel Corp. v. UMW, 383 F. Supp. 1082 (N.D. Ala. 1974), rev'd, 519 F.2d 1236 (5th Cir. 1975), cert. denied, 96 S. Ct. 3221 (1976).

53. See note 32 supra and accompanying text.

54. 383 F. Supp. at 1090. 
continued disobedience of court orders. ${ }^{55}$ The court concluded that the injunction failed for both overbreadth ${ }^{56}$ and vagueness. ${ }^{57}$

The Court of Appeals for the Third Circuit considered the issue of prospective Boys Markets relief in United States Steel Corp. v. UMW (U.S. Steel (3d Cir.)). ${ }^{58}$ The Third Circuit reached the same conclusion as did the Fifth Circuit in its U.S. Steel case, but through utilization of somewhat different criteria. The injunction which the UMW appealed to the Third Circuit was based on district court findings ${ }^{59}$ that a series of illegal work stoppages had occurred within the previous twelve-month period. ${ }^{60}$ The injunction issued by the district court, like those in Old Ben II and U.S. Steel (5th Cir.), ordered the defendants to cease striking and to refrain from picketing or interfering with operations "because of any difference concerning the meaning and application of the provisions of the Agreement [1974 NBCWA] or any difference about matters not specifically mentioned in the Agreement or because of any local trouble of any kind arising at the mine." 61 In addition, the injunction ordered compliance with the NBCWA's "Settlement of Disputes" procedures for resolution of three specific grievances $^{62}$ and any other "differences . . . as to the meaning and application

55. $519 \mathrm{~F} .2 \mathrm{~d}$ at 1245 .

56. The court of appeals asserted that the district court, by the issuance of what was in effect an injunction against striking for the life of the contract, had promoted one of the principal abuses at which the Norris-LaGuardia Act was aimed-injunctive overbreadth. See note 8 supra and accompanying text. "The carefully drawn guidelines in Boys Markets clearly call for case-by-case adjudication." 519 F.2d at 1245 . The court further-believed that the district court's position would compel the union to litigate the applicability of Boys Markets injunctive relief in contempt proceedings, id., a predicament strongly reminiscent of "government by injunction." See notes 8-9 supra and accompanying text.

57. The court relied on section 9 of the Norris-LaGuardia Act, 29 U.S.C. $\S 109$ (1970), focusing on its directive that only acts specified in the complaint may be enjoined (and then only after the court has made findings of fact which support the allegations in the complaint), and Federal Rule of Civil Procedure 65(d), which incorporates due process notice requirements by mandating specificity in the language of the injunction. Judge Wisdom assailed the rationale advanced by the Seventh Circuit in Old Ben II-that the injunction was not vague because it employed language of the parties' contractual agreement, see text accompanying note 42 supra -noting that a "collective bargaining agreement . . . is anything but a precise document . . ." 519 F.2d at 1246. He concluded that the injunction must fail for vagueness because it substituted "nebulous contractual terms" for specific descriptions of particular acts. Id. n.19. See notes 90-92 \& 98-106 infra and accompanying text.

58. 534 F.2d 1063 (3d Cir. 1976).

59. United States Steel Corp. v. UMW, 393 F. Supp. 936 (W.D. Pa. 1975), rev'd, 534 F.2d 1063 (3d Cir. 1976).

60. 393 F. Supp. at 939 . Each dispute had been subject to resolution under the Settlement of Disputes procedures of either the 1971 or 1974 NBCWA.

61. 534 F.2d at 1066.

62. The three stoppages which resulted in the order were sparked by (1) a dispute as to whether the company must furnish parking lot security guards at night, (2) disagreement over whether employees had the right to refuse to work with another employee who had worked during a previous illegal work stoppage, and (3) a seniority dispute involving the filling of temporary vacancies. Four other work stoppages had occurred in the same twelve-month period. $I d$. 
of the provisions of [the] agreement," "differences . . . about matters specifically mentioned in [the] agreement . . . [or] any local trouble of any kind arising at the mine ..."63 The Third Circuit held that while the district court could properly have issued a Boys Markets injunction to enforce the NBCWA grievance-arbitration provisions, the injunction that was issued by the district court had to be vacated because it was overbroad and not sufficiently specific. ${ }^{64}$

The issue of prospective injunctive relief was considered most recently by the Court of Appeals for the Ninth Circuit in Donovan Construction Co. v. Construction Laborers Local 383.65 The recurring objections of overbreadth and contravention of Norris-LaGuardia policy were voiced in the umon's appeal of an injunctive decree, which enjoined it from "engaging in any strike or work stoppage or a threat of a work stoppage at the operations of plaintiff at the Umited States Veterans Hospital . . . concerning matters which are subject to being resolved by procedures contained in labor agreements by which plaintiffs and defendants are bound." 66 Acknowledging the inherent complications which are present when a court faces an anticipated rather than present controversy, the Ninth Circuit announced its

63. Id. at 1066-67.

64. Id. at 1078. On the issue of overbreadth, the court noted that, in general, prospective relief may be justified by considerations of judicial economy; once a federal court has ascertained the meaning of a labor agreement in a section 301 suit, it should not be subjected to endless relitigation of the same question in slightly different contexts. Id. at 1077. The court insisted that injunctive relief can encompass a "pattern of ongoing activity," id., but that the prospective relief should go no further than the pattern of violations suggests is necessary. The district court must find, in other words, that prior types of violations are likely to recur, or that new types of violations are likely to occur in the future. Id. The court suggested its own checklist of conditions to be met for such injunctive relief:

Before prospective injunctive relief is ordered the district court must, we think, make specific findings based on evidence in the record as to the types of violations which have occured in the past and limit injunctive relief to the likelihood of their recurrence, or to new and different kinds of violations which may be expeted to occur in the future.

Id. (emphasis added).

The court also found the district court's injunction to be impermissibly vague because it failed to instruct the officers of the union what steps they would be required to take to prevent illegal work stoppages from recurring. Id. at 1077-78.

Judge Rosenn, concurring, agreed with the prerequisite for injunctive relief set out in Judge Gibbons' majority opinion. Id. at 1082 . Judge Rosenn understood the majority opinion to say only that the broadly framed injunction issued by the district court was not warranted on the evidence before the court; he did not read the majority as prohibiting such a broad prospective injunction in all cases. Id. at 1081. According to his concurrence, the broad injunctive relief framed in the language of the contract would be appropriate when the pattern of past union violations could not reasonably be categorized. $I d$. at 1082 .

65. 533 F.2d 481 (9th Cir. 1976).

66. Id. at 485 . The dispute in this case concerned the respective rights of competing unions to do certain work. The employer-union contract had a no-strike clause specifically applicable to jurisdictional disputes which directed their submission to the National Joint Board for Settlement of Jurisdiction Disputes. Id. at 483. 
approval of prospective injunctive relief where the plaintiff-employer can demonstrate likelihood of recurrence and magnitude of threatened harm which are sufficient to satisfy Boys Markets standards. ${ }^{67}$ The court concluded, however, that the record failed to show evidence "that future strikes were likely, that they would cause irreparable harm, that there was no adequate remedy at law or that the employer would suffer more from the denial of the injunction than would the union from its issuance." 68 The case was remanded to the district court with directions to modify its order so as to enjoin only those strikes, work stoppages or threats thereof which were "incident to a jurisdictional dispute substantially similar" to the underlying dispute. ${ }^{69}$

67. Id. at 484. The court noted the narrowness of the Boys Markets exception to the anti-injunction provisions of the Norris-LaGuardia Act and the consequent stringency of qualifying specifications. Quoting Justice Brennan's Sinclair dissent, see notes 23-24 \& 32 supra and accompanying text, the Ninth Circuit "read this to mean that each restraint imposed by a Boys Markets injunction must be grounded on a finding by the District Court that the activity restrained is a proper subject for injunctive relief despite the Norris-LaGuardia Act." $533 \mathrm{~F} .2 \mathrm{~d}$ at 485 . The court also suggested a way to assess overbreadth: if the language of the injunction is sufficiently broad in scope that it would authorize enjoining an activity which is absent from the fact situation in the suit presently before the court, then the injunction exceeds Boys Markets bounds and must fall under the anti-injunctive provisions of the NorrisLaGuardia Act. Id. at 485-86.

68. Id. at 486.

69. Id. In addition to the six cases discussed supra in this section, two other courts of appeals have addressed tangentially the question of broad prospective injunctions when faced with the problem of interpreting particular injunctive orders.

In General Dynamics Corp. v. Local 5, Indus. Union of Marine \& Shipbuilding Workers, 469 F.2d 848 (1st Cir. 1972), the First Circuit heard the plaintiff-employer's complaint of union non-compliance with an arbitrator's award which had ordered striking employees to return to work. The arbitrator's order stated: "Employees who have participated in this prohibited work stoppage are directed to refrain from such conduct forthwith and return to work immediately and cease and desist from any such further contract violations." Id. at 851 (emphasis added). The court considered alternate interpretations of the "final Delphic phrase": either it was intended to bar any further work stoppage like those found by the arbitrator to have occurred on three named occasions relating to seniority disputes, or it was intended to bar any further work stoppage in violation of the collective bargaining agreement. Id. The court opted for the former restrictive interpretation, anticipating Norris-LaGuardia difficulties with injunctive orders susceptible of application to an indefinite number of yet-uncommenced strike actions. "In an area where our power is grounded in the policy of enforcing the will of the parties," the court concluded, "we would not even entertain such a sweeping order unless it was perfectly clear that the parties so intended. Even then we would be most cautious in issuing an order which would in effect involve relinquishment of an equity court's obligation to weigh the circumstances and exercise its discretion in each instance." Id. at 852.

The Second Circuit, in New York Tel. Co. v. Communications Workers, 445 F.2d 39 (1971), heard a union appeal from an order drawn by the district court and from a judgment of civil contempt for violation of that order. The temporary restraining order echoed the language of plaintiff-employer's complaint seeking an injunction against "engaging in . . . any strike, work stoppage, boycott of overtime work, slowdown or other form of interference with the business of the plaintiff." Id. at 42 . The Second Circuit concluded that the order, despite its broad language, was meant to apply only to the switchmen's transfer dispute then occurring in Brooklyn and not to subsequent overtime allocation disputes. The court explained: 


\section{LEGAL ARGUMENTS AND ANALYSIS}

The Iegal arguments presented in the opinions of the courts of appeaIs address themselves primarily to the two major defects to which prospective injunctions are susceptible - vagueness and overbreadth. Overbreadth of an injunction refers to the range of activity it proscribes; vagueness refers to the specificity with which the injunctive order describes the proscribed activity. ${ }^{70}$

\section{Vagueness}

The principal dangers inherent in vague injunctive decrees are their excessive deterrent effect on cautious defendants who fear contempt sanctions, and the invitation they present to others to utilize the vagueness intentionally to evade the order's proscriptions. ${ }^{71}$ The chief legal weapons which have been used to attack prospective Boys Markets injunctions on vagueness grounds are section 9 of the Norris-LaGuardia Act $^{72}$ and Rule 65(d) of the Federal Rules of Civil Procedure. Section 9 provides that:

No restraining order or temporary or permanent injunction shall be granted in a case involving or growing out of a labor dispute, except on the basis of findings of fact made and filed by the court in the record of the case prior to the issuance of such restraining order or injunction; and every restraining order or injunction granted in a case involving . . . a labor dispute shall include only a prohibition of such specific act or acts as may be expressly complained of in the bill of complaint or petition filed in such case and as shall be expressly included in said findings of fact made and filed by the court as provided in this chapter. ${ }^{73}$

The demands of section 9 were considered by the Fifth, Tenth, and Third Circuits. In U.S. Steel (5th Cir.), the court of appeals, reviewing an injunction which prohibited work stoppages "over any disagreement about the interpretation . . . of the collective bargaining agreement . . . or . . . any matter not mentioned in said agreement, or over local trouble of any kind," "74 eniphasized section 9's command of specification of the acts to be

[I]n those limited situations where federal courts can intervene by way of injunction, they must do so hesitantly and avoid blanket prohibitions. We feel impelled to implement that Congressional policy by narrowly construing restraining orders and injunctions issued in labor disputes, inasmuch as the generality of court orders in Id. at 49.

such cases was one of the chief abuses which led to the Norris-LaGuardia Act.

70. See Developments in the Law-Injunctions, 78 HARv. L. Rev. 994, 1064 (1965). See also United States Steel Corp. v. UMW, 519 F.2d 1236, 1246-47 \& n.19 (5th Cir. 1975), cert. denied, 96 S. Ct. 3221 (1976).

71. Developments in the Law-Injunctions, supra note 70, at 1065.

72. 29 U.S.C. § 109 (1970).

73. Id. (emphasis added).

74. United States Steel Corp. v. UMW, 519 F.2d 1236, 1239 (5th Cir. 1975), cert. denied, 96

S. Ct. 3221 (1976). 
enjoined. The court concluded that where no specific act was either complained of in the plaintiff-employer's motion for the injunction or prohibited by the injunction, the injunction could not stand. ${ }^{75}$

The Tenth Circuit, reviewing a far more specific injunctive order, ${ }^{76}$ emphasized the notice-giving function of section 9. The court considered a union argument that since the complaint in which the injunction was sought mentioned only one work stoppage, the injunction should have been confined to that single violation. It was concluded that whatever ambiguities existed in the pleadings, the union had received fair warning from the course of the evidence at trial that the district court was considering the union's entire record of past misconduct and would frame its injunction according$1 y .{ }^{77}$ This is a commendably practical interpretation of section 9 , the purpose of which is not to assure technical uniformity between complaint and injunction but to prevent "harsh inclusive injunctive orders which . . . go, by the embracive character of the decree, beyond the allegations of the complaint or the facts adduced." 78

The precise position of the Third Circuit on the need for compliance with the specificity requirements of section 9 remains uncertain, obscured by the ambiguity of Judge Gibbons' remarks on the subject. ${ }^{79}$ In U.S. Steel (3d Cir.), Judge Gibbons recommended an accommodation approach to section $9^{80}$ under which, presumably, the required degree of specificity regarding the acts to be enjoined would be tempered by the pro-arbitration goals of section 301 of the Taft-Hartley Act. ${ }^{81}$

This is an unjustified distortion of the principle of accommodation as it has been applied in the area of injunctive relief for breaches of no-strike clauses in labor contracts. ${ }^{82}$ The Boys Markets Court, in engineering the original accommodation between the Norris-LaGuardia Act and section 301 , created a narrow exception to the anti-injunctive provision of the Norris-LaGuardia Act where such an exception was necessary to accomplish

75. 519 F.2d at 1246.

76. CF\&I Steel Corp. v. UMW, 507 F.2d 170, 173 (10th Cir. 1974). See text accompanying note 47 supra.

77. 507 F.2d at 176. The Third Circuit's opinion in U.S. Steel (3d Cir.) characterized the Tenth Circuit's CF\&I decision as "holding that $\$ 9$ permits a prospective injunction where the complaint gives fair warning that past violations will be relied upon as a basis for an injunction against future violations." United States Steel Corp. v. UMW, 534 F.2d 1063, 1076 (3d Cir. 1976).

78. Report of the House Committee on the Judiciary (1932), quoted in STATUTORY HISTORY, supra note 8, at 202.

79. Indeed, at one point in the U.S. Steel opinion, Judge Gibbons treated section 9 as dealing with overbreadth and not vagueness. See note 115 infra.

80. United States Steel Corp. v. UMW, 534 F.2d 1063, 1075-76 (3d Cir. 1976).

81. See notes 13-15 supra and accompanying text.

82. See notes 22-29 supra and accompanying text. 
the purposes of the Taft-Hartley Act through contract arbitration. ${ }^{83}$ The Court was dealing with section 4 of the Norris-LaGuardia Act ${ }^{84}$-a listing of prohibitions against specific injunctive application; however, Boys Markets implied no similar endorsement for limitation on or exception to the procedural safeguards provided by section 9 of Norris-LaGuardia. ${ }^{85}$ Accommodation was authorized only to the extent that the earlier (Norris-LaGuardia) statute was inconsistent with the goals of the later enactment (TaftHartley) ${ }^{86}$ There should have been no compromise of section 9's requirements in the circumstances considered by the Third Circuit, for there was clearly no conflict between the procedural demand of section 9-that the court enjoin only those specific acts complained of which it has, in fact, found to exist-and the Taft-Hartley policy of promoting contract arbitration for the solution of labor disputes. ${ }^{87}$

Rule 65(d), which is entitled "Form and Scope of Injunction or Restraining Order," provides: "Every order granting an injunction and every restraining order shall set forth the reasons for its issuance; shall be specific in terms; shall describe in reasonable detail, and not by reference to the complaint or other document, the act or acts sought to be restrained .88 In U.S. Steel (5th Cir.), the court found the injunction before it ${ }^{89}$ to be in violation of Rule 65(d) and elaborated on the elementary due process requirement of notice which the rule embodies. ${ }^{90}$ The importance of adequate notice, as the court indicated, is magmified by the power of the judicial contempt sanction ${ }^{91}$ standing behind the injunctive decree..$^{92}$

The Third Circuit made a similar reference to Rule 65(d) and its attendant contempt sanctions, adding that the language of the injunctive order before $\mathrm{it}^{93}$ " "hardly seem[ed] the kind of notice contemplated by the rule." "94 Judge Rosenn, in his concurring opimion, discussed in greater depth

83. See 398 U.S. $235,250-53$ (1970). See notes $25-32$ supra and accompanying text.

84. 29 U.S.C. 104 (1970).

85. Indeed, the Third Circuit acknowledged the limited application of the Boys Markets accommodation elsewhere. See United States Steel Corp. v. UMW, 456 F.2d 483, 487-88 (3d Cir. 1972).

86. See Virginian Ry. v. Sýstem Federation No. 40, 300 U.S. 515 (1937).

87. See New York Tel. Co. v. Communications Workers, 445 F.2d 39, 49-50 (2d Cir. 1971).

88. Fed. R. Civ. P. 65(d).

89. See text accompanying note 51 supra.

90. United States Steel Corp. v. UMW, 519 F.2d 1236, 1245-46 (5th Cir. 1975), cert. denied, 96 S. Ct. 3221 (1976).

91. See generally 11 C. Wright \& A. Miller, Federal Practice ANd Procedure § 2960, at 588-91 (1973).

92. See also Schmidt v. Lessard, 414 U.S. 473 (1974).

93. See text accompanying notes 61-63 supra.

94. United States Steel Corp. v. UMW, 534 F.2d 1063, 1076 (3d Cir. 1976). Judge Gibbons did not discuss the kind of notice required by the rule where an injunction is sought against a broad range of future violations. His "notice-vagueness" discussion, $i d$. at 1077-78, was limited to the particular demands of the wildcat strike situation where union officers must be advised of what steps should have been taken with respect to past violations and what prophylactic 
the question of whether the injunctive language was sufficiently specific to comply with the rule. He considered the problem to be especially vexing with respect to the prospective application of injunctive relief- "the inevitable imprecision of language attempting to deal with a fact situation still to unfold." "95 Therefore, he urged a "common sense" approach to Rule 65(d), emphasizing its demand for only "reasonable" detail. ${ }^{96}$ Judge Rosenn agreed that when past violations could be reasonably categorized, the order should do so, but proposed that when the range of previous violations by a union defied precise categorization, the injunction should be drawn broadly enough to prevent evasion. ${ }^{97}$

While "reasonableness" may justify a sliding scale approach to the degree of injunctive specificity, any "sliding" must be consistent with the purpose of Rule 65 , which is to provide adequate notice. Thus, specificity requirements should be lowered because of the knowledge already possessed by the party to be enjoined, and not because of the broad range of past violations (as Judge Rosenn's opimion would have allowed). In the case of a sufficiently egregious record of past misconduct, Judge Rosenn's analysis would presumably allow a union to be subjected to a prospective decree which said, in effect, that any future concerted activity would be prohibited, even though the vagueness of such a decree would completely defeat the notice function.

Attempts have been made to counter union charges of injunctive vagueness by arguing that union defendants do possess sufficient prior knowledge to obviate Rule 65(d) difficulties. That argument, most vigorously asserted by the Seventh Circuit in Old Ben $I,{ }^{98}$ is built on the use of language from the parties' contractual agreement (the NBCWA) in wording the injunctive order. ${ }^{99}$ The Seventh Circuit recited with some disbelief the union argument that it would not know when it could or could not strike ${ }^{100}$ -

measures are required if the union is to avoid contempt sanctions for future unauthorized strikes by its members. For further discussion of union liability for wildcat strikes, see Fishman \& Brown, Union Responsibility for Wildcat Strikes, 21 WAYNE L. REV. 1017 (1975).

95. 534 F.2d at 1083 (Rosenn, J., concurring).

96. Id.

97. Id. Judge Rosenn's opinion appears to require that the district court's order always be as specific as possible under the circumstances of the case. He would uphold "the use of carefully considered language broadly restraining strikes over arbitrable grievances, especially if it can be joined with specific language, to provide effective relief." Id. (emphasis added). His approach seems potentially self-contradictory, in that it would allow very broad injunctions as long as the injunction uses "carefully considered, specific" language. Since Judge Rosenn did not evaluate the injunction before the court, the workings of his paradoxical rule remain unclear.

98. Old Ben Coal Corp. v. Local 1487 UMW, 500 F.2d 950, 953 (7th Cir. 1974).

99. See notes 42 \& 51 supra and accompanying text.

100. 500 F.2d at 953. Judge Rosenn, in his U.S. Steel (3d Cir.) concurrence, voiced similar confidence that controversies about the interpretation of the injunction would be few. "Even where the injunction broadly prohibits strikes over any arbitrable grievance, arbitrability of 
in essence, that it did not know what "differences" or "local troubles" were arbitrable. ${ }^{101}$ The court rejected the union's argument, holding that " 'the incorporation of the parties' own contractual language into the injunction is of sufficient specificity to avoid the complaint of vagueness." 102

The Fifth Circuit found this argument unconvincing, ${ }^{103}$ noting that a "collective bargaining agreement . . . is anything but a precise document . . . "104 This analysis of the nature of a collective bargaining agreement is clearly more accurate than that implicit in Old Ben $I I$. Even if the agreement were a simple two-party contract, ${ }^{105}$ the parties could not supply precise standards to regulate all potential conflicts in their relationship because of the impossibility of predicting with accuracy the nature and conditions of that relationship three years into the future. ${ }^{106}$

The objection to injunctive vagueness is related to the need for adequate warning before the imposition of contempt penalties. Regardless of

grievances growing out of working conditions will seldom be in doubt in today's labor law." United States Steel Corp. v. UMW, 534 F.2d 1063, 1083 (3d Cir. 1976) (Rosenn, J., concurring).

Both the Old Ben II court, 500 F.2d at 953-54, and Judge Rosenn, 534 F.2d at 1083 \& n. 12, noted that in the few cases where the union was in doubt whether a grievance was arbitrable, and hence whether a strike over such grievance was prohibited by the injunction, declaratory relief would be available to the union.

101. This is hardly a claim which should evoke such incredulity. For example, in 1974 a group of Pennsylvania miners bound by the same collective bargaining agreement (NBCWA) conducted a strike in protest of inadequate safety conditions in the mine. The company brought a section 301 action for injunctive relief, arguing that the NBCWA's broad arbitration clause encompassed the safety dispute. The district court entered a preliminary injunction which was later vacated by the Third Circuit on the ground that safety disputes were not specifically included in the NBCWA and were not among the grievances to which the federal pro-arbitration labor policy applied. Gateway Coal v. UMW, 466 F.2d 1157 (3d Cir. 1972). The Supreme Court, with Justice Douglas dissenting, reversed the court of appeals decision, holding that the arbitration clause was sufficiently broad to encompass the safety dispute. Gateway Coal v. UMW, 414 U.S. 368 (1974).

102. 500 F.2d at 953.

103. See note 57 supra.

104. United States Steel Corp. v. UMW, 519 F.2d 1236, 1246 (5th Cir. 1975), cert. denied, 96 S. Ct. 3221 (1976).

105. The National Bituminous Coal Wage Agreement of 1974 seeks to regulate relations between the United Mine Workers of America and the Bituminous Coal Operators' Association which is composed of more than sixty coal companies, corporations and associations, many of which represent two or more smaller companies. National Bituminous Coal Wage Agreement 132 (1974).

106. See Shulman, Reason, Contract, and Law in Labor Relations, 68 HARv. L. REv. 999, 1002-04 (1955):

[N] gotiations are necessarily conducted by representatives removed in variant degrees from direct confrontation with the anticipated situations : . . . [T] here is never enough time to think every issue through in all its possible applications . . . [ [T] here is almost irresistible pressure to find a verbal formula which is acceptable, even though its meaning to the two sides may in fact differ. The urge . . . to clarify a felt ambiguity in the language . . . is at times repressed, lest the effort result in disagreement or in subsequent enforced consent to a clearer provision which is, however, less faviorable to the party with the urge. With agreements reached as to known recurring situations, questions as to application to more difficult cases may be tiredly brushed aside on the theory that those cases will never-or hardly ever-arise. 
where the equities lie on the basis of patterns of past conduct, the union must have explicit notice of precisely what conduct is to be forbidden in the future. The only injunctive order of those reviewed by the courts of appeals which assured such warning was the injunction approved by the Tenth Circuit in CF\&I. ${ }^{107}$ The order restrained specific concerted activity"strike, work stoppage, interruption of work or picketing at the Allen mine" - and delineated precise boundaries of applicability- "over disputes arising from employee suspensions, employee discharges and work assignments." 108 This precisely drawn order demonstrates that it is possible to issue a prospective injunction which achieves the proper accommodation between Norris-LaGuardia's anti-injunctive provisions and Taft-Hartley's section 301. Such an order adequately protects the employer from future strikes over arbitrable grievances, and it is accomplished without compromise of the statutory requirements, thereby avoiding the dangers inherent in vague injunctions. ${ }^{109}$

\section{Overbreadth}

Overbreadth, in contrast to vagueness, involves not linguistic specificity but the scope of the conduct to which the injunction applies. The circuit court opinions addressing the issue of overbreadth reflect some common philosophical ground, principally in the interpretation of Justice Brennan's Sinclair dissent and the Boys Markets decision. However, the dissimilarity of the factual situations faced by the respective courts prevents meaningful comparison of the courts' positions. It may be helpful, therefore, to examine the courts' overbreadth analysis in two hypothetical contexts. In the first, assume a clearly categorizable record of union violations against which a prospective injunction is sought. In the second, assume an extensive history of past union misconduct, but of such a diversity of subject matter as to defy categorization, against which a broad injunction preventing all future strikes is sought.

Categorizable activity. The Seventh Circuit would certainly approve an injunction against clearly categorizable activity, for it sanctioned far broader relief in Old Ben $I .{ }^{110}$ The opinion of the Tenth Circuit in $C F \& I^{111}$

107. CF\&I Steel Corp. v. UMW, 507 F.2d 170 (10th Cir. 1974).

108. Id. at 173.

109. Judge Rosenn's opinion made it clear that the possibility for multiple interpretation is never entirely eliminated. Referring to the injunction in $C F \& I$, for example, he asked whether a strike in response to a layoff was in violation of an injunction against strikes "over disputes arising from employee suspensions, employee discharges and work assignments." United States Steel Corp. v. UMW, S34 F.2d 1063, 1083 n.11 (3d Cir. 1976) (Rosenn, J., concurring).

-110. Old Ben Coal Corp. v. Local 1487 UMW, 500 F.2d 950 (7th Cir. 1974). See notes 40-43 supra and accompanying text.

111. CF\&I Steel Corp. v. UMW, 507 F.2d 170 (10th Cir. 1974). See notes $44-49$ supra and accompanying text. 
also suggests approval, ${ }^{112}$ since the injunction upheld by that court restrained specific concerted activity in three categories of disputes. ${ }^{113}$ Judge Gibbons, writing for the Third Circuit in U.S. Steel (3rd Cir.), ${ }^{114}$ clearly endorsed such injunctive relief, stressing the notion of judicial economy; that is, a court which has once interpreted a contract (and found that a particular type of grievance is arbitrable) must have the power to protect the parties from the necessity and burden of endlessly relitigating the identical issue. ${ }^{115}$ Judge Rosenn, concurring in the same case, agreed. ${ }^{116}$ The injunction considered by the Ninth Circuit in Donovan ${ }^{117}$ was based on a single violation, and the decree, ${ }^{118}$ as modified by the court of appeals, is a paradigm of the single-category prospective injunction.

Only the Fifth Circuit has shown reluctance to endorse any form of prospective injunctive relief, even in a situation where past union misconduct was clearly categorizable. At no time in the U.S. Steel (5th Cir.) $)^{119}$ decision did Judge Wisdom declare prospective application to future occurrences untenable, ${ }^{120}$ but the opinion vigorously supported the necessity under Boys Markets of a case-by-case adjudication of the arbitrability of the grievance sought to be enjoined. ${ }^{121}$ Additionally, the court criticized an

112. See note 48 supra and accompanying text.

113. See notes 108-09 supra and accompanying text.

114. United States Steel Corp. v. UMW, 534 F.2d 1063 (3d Cir. 1976). See notes 58-64 supra and accompanying text.

115. 534 F.2d at 1077: "If the plaintiff in a $\$ 301$ suit pleads and proves that the defendant . . . is engaging in a pattern of conduct which results in repeated and similar violations, nothing in $\$ 9$ of the Norris-LaGuardia Act, as we read it, prevents an injunction directed at such a course of conduct." The court appeared to be treating section 9 as prohibiting injunctive overbreadth as well as vagueness. The two concepts do overlap somewhat, and the Third Circuit's position with respect to section 9 is therefore not very clear. See notes 77-81 supra and accompanying text. It is clear, however, that the court would permit prospective injunction of particular categories of misconduct.

116. 534 F.2d at 1081-82 (Rosenn, J., concurring): "If the district court finds that strikes have occurred and likely will occur over two types of arbitrable grievances, e.g., employee suspensions and vacation pay, the injunction can be limited to enjoining future strikes over only these categories of grievances."

117. Donovan Constr. Co. v. Construction Laborers Local 383, 533 F.2d 481 (9th Cir. 1976). See notes 65-68 supra and accompanying text.

118. See text accompanying note 68 supra.

119. United States Steel Corp. v. UMW, 519 F.2d 1236 (5th Cir. 1975), cert. denied, 96 S. Ct. 3221 (1976). See notes 50-57 supra and accompanying text.

120. The decision declared only that a prospective injunction drawn as broadly as the NBCWA contract was impermissible. 519 F.2d at 1245-46. U.S. Steel (5th Cir.) did not involve a narrow single-category prospective injunction, but rather a very broad injunction prohibiting all strikes over any issue for the life of the contract, and the Fifth Circuit's statements must be read with that in mind. Furthermore, the court had grounds other than the overbreadth and vagueness of the order itself for reversing the district court's injunction; the strike was a "memorial protest" over the national policy permitting the importation of South African coal and was not over an arbitrable grievance at all. Id. at 1247-48.

121. See id. at 1245. 
argument made by the district court ${ }^{122}$ that Boys Markets clearly contemplated future relief in its requirement of a district court finding as to "whether breaches are occurring and will continue, or have been threatened and will be committed." 123 Judge Wisdom suggested that the district court had read too much into that language in justifying prospective injunctive relief, because the same findings were mandated by the Norris-LaGuardia Act, ${ }^{124}$ in almost identical terms, before the issuance of any labor injunction. 125

While this may indicate that the Fifth Circuit will not allow any form of prospective relief, the single-category prospective injunction might be acceptable, since the only grievance enjoined would have already been determined to be arbitrable by the district court using a "case-by-case" analysis. If the Fifth Circuit is, on the other hand, really announcing a policy in opposition to any prospective extension of Boys Markets relief, ${ }^{126}$ its position would be an unreasonable one. The likelihood that there would occur a strike in violation of the single-category prospective injunction (thus, by definition, over a grievance already determined to be arbitrable) for which the equities would not favor issuance of another injunction ${ }^{127}$ is small, and it is clearly outweighed by the considerations of judicial economy ${ }^{128}$ emphasized by the Third Circuit. ${ }^{129}$

122. The district court's rationale had previously been employed by the Tenth Circuit in CF\&I, see notes 48-60 supra and accompanying text.

123. Boys Markets, Inc. v. Retail Clerks Local 770, 398 U.S. 235, 254 (1970) (quoting Sinclair Ref. Co. v. Atkinson, 370 U.S. 195, 228 (1962) (Brennan, J., dissenting)).

124. No court of the United States shall have jurisdiction to issue a temporary or permanent injunction in any case involving or growing out of a labor dispute . . except after findings of fact by the court, to the effect-

(a) That unlawful acts have been threatened and will be committed unless

restrained or have been committed and will be continued unless restrained . . . .

29 U.S.C. $\$$ I07(a) (1970).

125. 519 F.2d at 1245 n.17.

126. The Third Circuit believed that the Fifth Circuit's opinion was meant to forbid all prospective injunctions: "Thus the Fifth Circuit seems to suggest that no injunctive relief against future violations would be proper . . . ."United States Steel Corp. v. UMW, 534 F.2d 1063, 1076 (3d Cir. 1976). However, later in the same paragraph, the Third Circuit noted that "[I]t is by no means clear that Judge Wisdom intended to suggest that injunctive relief is entirely unavailable...."Id.

127. The Boys Markets Court, adopting the Sinclair dissent, announced that as a precondition to the issuance of an injunction, the district court must determine whether issuance is warranted under ordinary principles of equity-" whether breaches are occurring and will continue, or have been threatened and will be committed; whether they have caused or will cause irreparable injury to the employer; and whether the employer will suffer more from the denial of an injunction than will the union from its issuance." Boys Markets, Inc. v. Retail Clerks Local 770, 398 U.S. 235, 254 (1970) (quoting Sinclair Ref. Co. v. Atkinson, 370 U.S. 195, 228 (1962) (Brennan, J., dissenting)).

128. See notes 114-15 supra and accompanying text.

129. That is to say, if a prospective injunction had not been issued in the first case, then when the next strike occurred the district court would first determine whether the grievance was arbitrable, and then weigh the equities to see if it should issue an injunction to stop the 
Diverse pattern of disputes. The second hypothetical fact situation, in which a broad range of activity is sought to be enjoined, finds the circuits more evenly divided. The Seventh Circuit has taken the most liberal position toward persissible injunctive breadth in Old Ben II. ${ }^{130}$ The court's proposed guideline that injunctive breadth and past union misconduct are to be coterminous $^{131}$ suggests Seventh Circuit support for the issuance of broad injunctions directed at activities whose variety precludes categorization. The court, in fact, showed little concern for categorization and none at all for the issue of arbitrability. ${ }^{132}$ Rather, it relied on the purely quantitative record of past union misconduct. ${ }^{133}$ The court did not catalogue the grievances which precipitated the strikes, but noted that most were of minor dimension. ${ }^{134}$

The enormous range of injunctive proscriptions which the Seventh Circuit seemed to endorse should, perhaps, be reduced somewhat by considering the Old Ben II decision in the context of Old Ben I. Although the court deleted the broad prospective provisions of the injunction in Old Ben $I,{ }^{135}$ it also declared that such relief would be appropriate under ccrtain circumstances-more specifically, if it should appear that "the Union is unwilling to accept the present adjudication with respect to its rights.",136 Thus, the Old Ben $I I$ opinion seems to derive a degree of legitimacy from the warning which the court issued to the union in Old Ben $I$ in the process of accepting overbreadth claims with respect to the earlier injunction. Absent this prior "warning," it is not clear that the Seventh Circuit would have taken such a permissive position in the second case.

current strike. (This is nothing more than a straightforward application of Boys Markets.) But since the first issue (arbitrability) has already been decided for this type of grievance in the prior case, judicial economy and fairness to the plaintiff-employer demand that it not be re-litigated; as to the second issue, a weighing of the equities would almost always call for the court to issue the injunction. Therefore, nothing is gained by repeating the analysis each time an identical grievance occurs, and the Third Circuit's judicial economy rationale argues persuasively in favor of the issuance of a single-category prospective injunction in the first instance.

130. Old Ben Coal Corp. v. Local 1487 UMW, 500 F.2d 950 (7th Cir. 1974). The injunction enjoined all work stoppages and strikes resulting from the discharge of a particular employee or from any other differences or local trouble which the parties were obligated to arbitrate under the 1971 NBCWA. Id. at 951.

131. Id. at 953. The court cited Boys Markets as authority for an injunction drawn broadly enough to aid the arbitration process between the parties according to their contractual agreement. Id.

132. See note 98 supra and accompanying text.

133. The record revealed the most extensive history of strike activity of any of the cases considered herein. During the final year and a half of the 1968 NBCWA, the union was involved in fourteen work stoppages, resulting in a loss of fifty-five work days. 500 F.2d at 950 . (The Old Ben $I$ case dealt with an injunction issued during that sequence of work stoppages.) After the signing of the 1971 NBCWA, eleven more strikes occurred. Id. at 952.

134. Id.

135. Old Ben Coal Corp. v. Local 1487 UMW, 457 F.2d 162, 165 (7th Cir. 1972). See note 38 supra and accompanying text.

136. 457 F.2d at 165 . 
The dimension of the injunctive order upheld in $C F \& I^{137}$ indicates the Tenth Circuit's opposition to an injunction prohibiting virtually any illegal work stoppage. The history of work stoppages considered in CF\&I encompassed a wide variety of arbitrable grievances, ${ }^{138}$ yet the district court refrained from issuing a broad injunction framed in terms of an identified "pattern" of striking over every arbitrable grievance. ${ }^{139}$ The district court instead isolated past work stoppages according to the subject of the grievances which precipitated them, and then determined which of the grievances were arbitrable and which were likely to recur. ${ }^{140}$ Its injunction, limited to prohibiting strikes involving the three categories of grievances which were likely to recur unless enjoined, was upheld by the Tenth Circuit.

The Tenth Circuit's position regarding the posited hypothetical, however, cannot be predicted with certainty. Although the end product approved in $C F \& I$ was commendably precise and narrowly drawn, the guidelines enunciated by the court were less restrictively tailored, and in other circumstances might well serve as authority for broader injunctive relief. The court quoted the 1941 Supreme Court case of NLRB v. Express Publishing Co. ${ }^{141}$ as the source of its standards for permissible injunctive breadth:

"The breadth of an order, like the injunction of a court, must depend upon the circumstances of each case, the purpose being to prevent violations, the threat of which in the future is indicated because of their similarity or relation to those unlawful acts the Board has found to have been committed by the employer in the past. . . . To justify an order restraining other violations it must appear that they bear some resemblance to that which the employer has committed or that the danger of their commission in the future is to be anticipated from the course of his conduct in the past." 142

The Express Publishing standards do not confine the scope of the injunction

137. CF\&I Steel Corp. v. UMW, 507 F.2d 170, 173 (10th Cir. 1974).

138. See text accompanying note 46 supra.

139. Although the injunctive relief was not drawn to encompass the entire record of past disputes, the Tenth Circuit recognized an "unlawful proclivity on the part of the Union to pursue a course of conduct in violation of the agreement of the parties and detrimental to the harmony of the relationship and the best interests of both labor and management." 507 F.2d at 176-77. Such misconduct, the court added, may properly be enjoined within "the limits found applicable." Id. at 177.

140. Id. at 172 .

141. 312 U.S. 426 (1941). In Express Publishing, the Court reviewed a decision enforcing an NLRB order which required the employer to cease and desist from refusing to bargain collectively and, further, to cease and desist from interfering with employees in the exercise of their rights under section 7 of the NLRA, 29 U.S.C. $\$ 157$ (1970).

142. CF\&I Steel Corp. v. UMW, 507 F.2d 170, 174 (10th Cir. 1974) (quoting NLRB v. Express Publishing Co., 312 U.S. 426, 436-37 (1941)) (emphasis added). While the language from Express Publishing is in reference to employer misconduct, it is clear that the Tenth Circuit was adopting this standard for judging the permissible breadth of injunctions aimed at union misconduct. 
to those specific categories of grievances which have caused strikes in the past and are likely to recur, but invite speculation as to different future disruptions predictable 143 and enjoinable solely because they may be "anticipated" from a prior pattern of conduct.

The CF\&I court's citation of Express Publishing as authority for broad injunctions to curb a demonstrated unlawful proclivity to strike has rightfully been criticized by both the Fifth and Third Circuits. Both courts pointed out that Express Publishing was distinguishable on its facts from the situations which they faced, since the standards enunciated in that case dealt with a regulatory injunction procured by an administrative agency which had broad authority to enforce a statutory policy. A Boys Markets suit, on the other hand, is authorized by a narrow exception to a statutory prohibition against injunctive relief. ${ }^{144}$

By the generality of the language in its U.S. Steel opinion, the Third Circuit appears to have reserved the option to decide either way on the permissibility of broad injunctive relief where the range of past grievances defies categorization. ${ }^{145}$ The court announced a position "somewhere between the extremes" suggested by the Fifth and Seventh Circuits, ${ }^{146}$ but it

143. The problems of predictability in a case where prospective injunctive relief is sought are enormous in and of themselves. The court must not only decide that, based on past conduct, a recurrence of a dispute is likely and that irreparable damage will occur in the future if the injunction is denied; it must also conclude that in each future violation, the employer would suffer more by denial of injunctive relief than would the union by its issuance.

144. United States Steel Corp. v. UMW, 534 F.2d 1063, 1076 (3d Cir. 1976):

[Express Publishing] lends no support for a $\$ 301$ injunction, for it involves a suit by a governmental agency to enforce a statutory policy, in which injunctive relief is expressly authorized by statute. In contrast, a Boys Markets suit is a private contract action which is a narrow exception to the statutory prohibition against injunctive relief.

United States Steel Corp. v. UMW, 519 F.2d 1236, 1247 n.21 (5th Cir. 1975). cert. denied, 96 S. Ct. 3221 (1976):

The crucial difference, as we see it, between those cases [Express Publishing and similar cases], and Boys Markets cases is that the former are public law cases, illustrating broader authority accorded administrative schemes of regulation . . . . It must be remembered that a $\$ 301$ suit is a private contract action.

145. The ambiguity of Judge Gibbons' majority opinion in U.S. Steel (3d Cir.) is illustratcd by the concurring opinion of Judge Rosenn, who believed that Judge Gibbons' opinion did not deny "the power of a district court to issue an injunction framed in the language of the arbitration clause of a collective bargaining agreement, broadly prohibiting strikes over any arbitrable grievance, where the facts before the court justify such an injunction." $534 \mathrm{~F} .2 \mathrm{~d}$ at 1081. Rather, Judge Rosenn understood "Judge Gibbons to state only that the broad injunction here was not warranted by the evidence before the district court." Id. The problem was that the evidence before the district court showed only three strikes over arbitrable grievances, and while the district court took judicial notice of four other stoppages, it did not determine whethcr those violations either were likely to recur or indicated a pattern from which it could be inferred that different violations would occur. Id. at 1082.

146. The Third Circuit reviewed the treatment of prospective Boys Markets relief by the other circuits, id. at 1075-77, and summarized: "[T]he Fifth Circuit seems to suggest that no injunctive relief against future violations would be proper, the Tenth Circuit holds that a prospective injunction against specifically identified types of future violations which have in 
failed specifically to ally itself with the position of the Tenth Circuit in CF\&I. Although the court recognized the need for ad hoc adjudication "relating the violation to the contract," 147 Judge Gibbons apparently did not deem case-by-case adjudication of arbitrability to be essential.

The Third Circuit endorsed an extension of the injunction before it to include "a pattern of conduct which results in repeated and similar violations," 148 but the court provided no definition of "similarity." 149 If "similar" is defined narrowly to include only grievances in the same category as those which have already occurred, then the most extensive injunction which it would approve might be no broader than the order approved in CF\&I; however, if it is defined in terms of the illegality of the activity alone-as part of a "chronic pattern of continuing mischief" 150 - then the court would apparently ratify an injunctive decree fully as broad in scope as that endorsed in Old Ben II, provided only that the district court made the appropriate findings. There is evidence in Judge Gibbons' opinion to indicate that the court was adopting the more permissive approach. In his guidelines to the district court, ${ }^{151}$ Judge Gibbons suggested that where the appropriate findings of fact were made, an injunction might be issued to prevent prior violations which were likely to recur or to prevent " new and different kinds of violations which [might] be expected to occur in the future." 152 This may, however, mean no more than that future violations of a new and different kind may be enjoined if they are sufficiently foreseeable as to be categorizable, but that injunctions forbidding all future strikes would be too broad to be approved.

Judge Rosenn, in his concurring opinion, stated very clearly that he would allow the district court to issue a broad injunction, framed in the language of the contract, if the union manifested "a proclivity to strike over every arbitrable grievance. . . [and] the grounds for future strikes cannot be adequately forecast . . . ."153 Judge Rosenn believed that the majority opinion had not rejected this approach, ${ }^{154}$ but it is not at all clear that Judge Gibbons had accepted it. Both the majority opinion and Judge Rosenn's concurrence would agree that where the union's misconduct was categor-

the past occurred is proper, and the Seventh Circuit holds that an injunction as broad as the contract is permitted." Id. at 1077. The Third Circuit declared its intention to follow a course "somewhere between the extremes." Id.

147. Id.

148. Id.

149. The same problem, with the same two possible interpretations, arises when one attempts to determine what the court meant by a "pattern of ongoing activity." Id.

150. Id.

151. See note 64 supra.

152. $534 \mathrm{~F} .2 \mathrm{~d}$ at 1077.

153. Id. at 1082 (Rosenn, J., concurring). See also id. at 1081 n.7.

154. See note 145 supra. 
izable, the injunction must be limited to enjoin only those categories of grievances; ${ }^{155}$ where the union's misconduct was not categorizable, however, it remains unclear whether the Third Circuit would permit a broad injunction.

The Ninth Circuit was not required to formulate a policy on injunctive breadth where the range of past grievances prevents categorization, for the record in Donovan presented only a single dispute. The question therefore remains open in the Ninth Circuit. However, the court's reaction to the district court's attempt to make the injunction effective against further illegal disruptions of any origin ${ }^{156}$ suggests Ninth Circuit opposition to injunctions as broad as that hypothesized.

There can be little doubt, of course, that the Fifth Circuit would actively oppose the broad injunctive relief suggested by the second hypothetical, ${ }^{157}$ given its demand for case-by-case adjudication of the arbitrability of the subject of dispute. ${ }^{158}$ The argument for individual analysis of underlying grievances is a compelling one. The exception to NorrisLaGuardia restraints pioneered by Boys Markets is invoked not by the occurrence of a strike, but by the contravention of the public policy favoring arbitration-a contravention which presupposes actual arbitrability of the underlying dispute. ${ }^{159}$ Therefore, a court should not issue an injunction, the breadth of which implies a prediction that all future grievances will be arbitrable; nor should the court require a union with a grievance of questionable arbitrability to postpone its strike, on pain of contempt, while eliciting a judicial determination of arbitrability.

The determination of the correct approach to the breadth of prospective injunctions, as an attempted widening of the crack opened by Boys Markets in Norris-LaGuardia's anti-injunctive policy, must be reached through the channels of accommodation endorsed in that decision. ${ }^{160}$ Justice Brennan proposed that the anti-injunctive provisions of Norris-LaGuardia be accommodated only in circumstances in which compliance with the restrictions was not vital to the achievement of Norris-LaGuardia objectives. ${ }^{161}$ When

155. See 534 F.2d at 1077 (majority opinion); id. at 1082 (Rosenn, J., concurring).

156. See Donovan Constr. Co. v. Construction Laborers Local 383, 533 F.2d 481, 485-86 (9th Cir. 1976).

157. Indeed, the U.S. Steel (5th Cir.) opinion can be read as forbidding all prospective Boys Markets relief, even where the union's misconduct is clearly categorizable. See notes 119-27 supra and accompanying text.

158. See United States Steel Corp. v. UMW, 519 F.2d 1236, 1245 (5th Cir. 1975), cert. denied, 96 S. Ct. 3221 (1976).

159. See Buffalo Forge Co. v. United Steelworkers, 96 S. Ct. 3141 (1976), discussed at note 33 supra.

160. See notes 28-29 supra and accompanying text.

161. Sinclair Ref. Co. v. Atkinson, 370 U.S. 195, 225 (1962) (Brennan, J., dissenting). See also Boys Markets, Inc. v. Retail Clerks Local 770, 398 U.S. 235, 253 (1970). The Boys Markets demand for present injunctive relief entailed no debasement of those objectives; bccause of the 
injunctive relief is given prospective instead of present application, the balance struck in Boys Markets may be shifted. Where prospectively applied injunctive relief surpasses mere assurance of union compliance with contractual duties and subjects unions to broad and indefinite restraints, the objectives of Norris-LaGuardia are frustrated far more than the proarbitration policy of section 301 is advanced. The correct measure of accommodation, then, is to permit prospective Boys Markets injunctions, but only where the injunction addresses specific categories of grievances; broad injunctions, prohibiting all future strikes over any grievance, are incompatible with the objectives of Norris-LaGuardia and should not be allowed.

\section{CONCLUSION}

The dominant import of the Norris-LaGuardia Act is that the judiciary must refrain from intervening in private contract disputes between management and labor by means of injunctive relief. The subsequent evolution of a strong governmental preference for arbitration legitimized a narrow exception and a limited measure of interference. Extension of this narrow exception to regulate future disputes-depending on the degree and nature of controls to which the extension is subject-may engender either a reasonable compromise, accomplished without substantially increasing the measure of interference, or a devastating impediment to the objectives of the Norris-LaGuardia Act.

The dangers inherent in prospective application of Boys Markets injunctive relief can be averted by applying a rigid standard of scrutiny to such injunctive decrees. The commands of specificity of section 9 of Norris-LaGuardia and Rule 65(d) of the Federal Rules of Civil Procedure must be closely adhered to without deviation for any purpose. The order must state precisely what conduct the court forbids, avoiding nebulous and ambiguous terms such as "similar" or "other arbitrable" disputes or "ongoing patterns of conduct," for " $[t]$ he most fundamental postulates of our legal order forbid the imposition of a penalty for disobeying a command that defies comprehension." 162 Overbreadth can be most effectively avoided by following the procedure suggested in Donovan: the court may issue an injunction broad enough to encompass only recurring disruption over those particular grievances which could presently have been enjoined on the basis

"quid pro quo" in the contractual arrangement, 398 U.S. at 252-53, each party surrendered an economic weapon of supposedly equal importance. See notes 23-24 supra and accompanying text. But see A. GOLDMAN, supra note 7, at 109 (arguing that the basic notion of "trade-off" in the contractual arrangement is itself a faulty one, for the employer is often equally anxious to arbitrate).

162. International Longshoremen's Ass'n v. Philadelphia Marine Trade Ass'n, 398 U.S 64, 76 (1967). 
of the factual information before the court at that time. ${ }^{163}$

In applying the Donovan procedure, courts should permit the issuance of prospective Boys Markets injunctions, so long as the order is properly limited to enjoin only specific categories of grievances. Admittedly, the imposition of these controls will do little to deter abusive repetition of illegal strike activity by unions where the strikes are not precipitated by the same recurring grievances. These inequities, however, must be rectified elsewhere. ${ }^{164}$ The answer does not lie in the unwarranted manipulation of congressional labor policy.

163. The injunction approved by the Tenth Circuit in $C F \& I$ exemplifies the type of decree which would be issued under the Donovan standards urged by this Note. However, while the $C F \& I$ injunction was commendably precise and narrowly drawn, the guidelines announced in $C F \& I$ may be read to approve less restrictively drawn orders. See text accompanying notes 141-42 supra. To that extent, CF\&I should not be followed.

164. An employer, for example, retains the alternative sanctions of disciplinary action and an action for damages. The Fifth Circuit concluded: "An employer may discipline its work force for failure to work. We are sympathetic to the company's plight, for we have no doubt that such discipline would precipitate further strikes . . . In light of the Norris-LaGuardia Act and the careful accommodation struck by Boys Markets, this Court cannot discipline the employees through contempt proceedings." United States Steel Corp. v. UMW, 519 F.2d 1236, 1248 (5th Cir. 1975), cert. denied, 96 S. Ct. 3221 (1976). It was noted that, while there had been a trend toward judicial intervention in labor disputes, that trend had not advanced to the level where the requested injunctive relief would be permissible. Further, the judiciary historically has hesitated to extend the injunctive remedy for the practical reason that an injunction must be enforced-by force if necessary-and labor law places a high priority on avoidance of civil strife. 519 F.2d at 1248 n.25. The Fifth Circuit deferred to Congress for ultimate resolution: "How far [the] courts can go in making collective bargaining agreements specifically enforceable in their entirety depends in large part on how much judicial intervention labor is willing to accept without resistance. This is a policy judgment best left to Congress." Id. 